\title{
Measuring Faculty Members' Readiness to Use E-learning in Social Work Education, Based on the Theory of Planned Behavior
}

\section{Ahmed K. A. Younes (PhD)}

Social Casework Department Faculty of Social Work- Helwan

University- Cairo- Egypt.

\section{Hanaa E. E. Shalapy (PhD)}

Social Casework Department Faculty of Social Work- Helwan University- Cairo- Egypt. 



\section{Measuring Faculty Members' Readiness to Use E- learning in Social Work Education, Based on the Theory of Planned Behavior}

Abstract: This study aims to measure how ready faculty members are to use e-learning in social work education in Egypt and Saudi Arabia. It will help decision makers to identify the important factors affecting faculty members' readiness to use e-learning, taking into account the Theory of Planned Behavior. A sample of 131 faculty members, representing faculties of social work in Egypt (59) and in Saudi Arabia (72), was selected to respond to a questionnaire. The results showed that the intention of faculty members to use e-learning in social work education is strong. The results also showed that there are no statistically significant differences between the study variables according to gender or workplace, but there are statistically significant differences between variables related to previous experience in the use of e-learning. Finally, the results indicated that the "Subjective Norms" is the most effective variable of planned behavior theory (PBT) in forming behavioral intention from the "Attitude Towards Behavior" and "Perceived Behavioral Control".

Keywords: Social Work Education - E-Learning - Planned Behavior.

\section{Introduction}

Discussion surrounding technology and the internet in particular, has become familiar within different strata of society on a global level including within the Arab world (Al-Zufairi, 2004, p.86).

The ITU Report (2017) indicates that the proportion of people using the internet in developed countries is $81 \%$, whereas internet use stands at $41.3 \%$ in developing countries. Due to the spread of technology and the internet, students at all levels of education are keen to use the internet for educational purposes which has resulted in the emergence of e-learning (Al-Zufairi, 2004, p.86). Nowadays, the need for establishing e-learning as a method of education has become more urgent, as the e-learning revolution has brought about several positive changes reflecting the progress of countries (Al-Muhaisen, 1429, pp.1-2). In fact, e-learning is considered an essential part of sustainable human development as it facilitates not only access to knowledge but enhancement of it as well. In addition, e-learning enables consumers to gain a diversity of skills and experiences as they are able to overcome distance and time constraints whilst studying (Othman, 2016, p.82). 
International universities are moving intensively towards elearning and distance education exploiting the advantages available on an economic level, through profits which can be generated by universities, and an academic level, through providing educational opportunities for people who may, for many reasons, face difficulties in enrolling in a traditional system of education. Moreover, e-learning contributes towards solving the problem of increasing numbers of people studying in higher education (Ba-Mefleh, 2006, p.23).

There exists accumulated evidence regarding the effectiveness of computer-assisted learning and its contributions to teaching (Eskander, 1985, p.40). For example, a study by Jerald G Schutte of the University of California showed that the grades of students who used the internet were $20 \%$ higher than those who had studied at the university using more traditional methods (Keegan, 2002, p.36). Also, e-learning has become more effective and stimulating since the creation of Web2.0 technology (Amasha, 2008, p.23).

However, the transition to e-learning in institutions of higher education demands a number of steps be taken first (pp. Al-Arabi, 2007, p.79): 1) Preparing educational content; 2) Determining the lecture plan; 3) Identifying groups of students to study via e-learning; 4) Managing the educational process; 5) Assessing students' performance; 6) Preparing reports and statistics.

It is noted that the biggest burden in implementing the abovementioned steps is shouldered by the faculty member. It is the faculty member who is capable of adopting and implementing modern technology in teaching in addition to interacting and communicating with students, which is one of the most important elements to creating a successful e-learning environment (Moselhi, \& Mohammad, 2007, p.86). It is true that an experienced faculty member plays the most pivotal role in the success of any e-learning program (Salmon, 2013, p.179).

Sherif's study (2013) ascertains the importance of preparing faculty members to deliver courses via e-learning, and training them to follow the process of technology development and use different electronic devices and software (p.102), Moreover, Recovita, Carbonero, \& Diaconu, (2018) Abdelghani, (2018) concluded that the most important challenges teaching staff face regarding online teaching are the provision of physical and human resources, provision of computers for the development of courses on the internet, the reduction of teaching loads and provision of the proper technical support and periodic maintenance of the equipment in lecture rooms. 
Educational technology innovations are not an end in themselves, they are important in the sense of how they are used in educational situations. This can only be achieved if the user is familiar with them and has the skills to use them effectively (Al-Sherbini, \& Abdul Hamid, 2012, p.632).

The application of e-learning should not detract from the real goals of education. E-learning is not teaching about technology, rather, it is learning by using technology (Al-Zufairi, 2004, p.87), Therefore, e-learning in education has been used by specialists in various fields including the field of social work. This is reflected in related literature that has described many experiences of using elearning in social work education.

Shorkey \& Uebel's study (2014) states that technology was introduced in 8 leading schools of social work between 1950 and 1960 using audiovisual technology. Then, computer-assisted social work education began in the early 1990s. By the late 1990s, education technology, including distance learning, interactive media and internet technologies, became widespread.

Madoc \& Parrott (2005) demonstrated that although e-learning in social work is a positive and empowering experience for students, a balance must be made between face-to-face interaction and online interaction so as to ensure that students are not isolated. East \& Alter (n.d.) confirmed that social work education will always be an integrated learning model including both direct interaction in field education and technology-enhanced education.

Research experiments have proven the effectiveness of elearning in social work education and identified various advantages. For example, Oterholm. (n.d.) aimed to identify the extent to which the use of e-learning enhances the critical thinking process. The study concludes that e-learning enhances the critical thinking of social work students through the use of chat and forum tools.

In addition, Bozalek \& Matthews (n.d.) revealed that the elearning experience has unexpectedly created a forum for intimacy with its broad concept of intellectual participation and emotional display among students throughout different geographical locations, and thus enhancing the participants' ability to work more effectively as professional practitioners.

Moreover, Quinney (2005) indicates that e-learning is beneficial in collaborative learning, resource sharing and communication, and is also presented in a flexible framework. 
The importance and benefits of the use of technology in social work education is evidenced by the set of standards governing the use of technology in social work education and practice issued by the National Association of Social Workers (NASW, 2017).

Nowadays, the use of e-learning has become a necessity. For technology to be available to students of social work and to prepare them for future jobs, depends on many aspects of its use. The question to be raised is not whether e-learning is good for social work education, but weather social work teachers are willing to use elearning in social work education. Related studies by Deepak, Wisner, \& Benton (2016), Webber, et al (n.d.) and Shorkey \& Uebel (2014) indicate that students are satisfied with e-learning as it increases their motivation and improves their chances of success. Therefore, Knowles. (n.d.) recommended that we need to investigate the perceptions of faculty members, especially those who do not use elearning, to better understand the relationships between their motivation, skill level, preferred teaching style, resources, teaching loads and rewards.

The extent to which the faculty members are willing to use elearning in social work education can be studied within various theoretical frameworks. However, the researchers decided to use the Theory of Planned Behavior (TPB). The rationale behind this decision is that it provides a strong theoretical framework through which the willingness of individuals to conduct a particular behavior can be predicted. The related literature provides evidence of the effectiveness of the theory and its ability to predict the willingness of individuals to conduct a certain behavior. For example, Francis et al (2004) reported that the TPB has attracted hundreds of researchers to adopt it. The literature also points out that from 1985 to 2004, 222 research studies published in the Medline database, and 610 studies published in the PsycINFO database, utilized the TPB as their theoretical framework. One of the most important areas in which researchers used the TPB is education. Lee, Cerreto \& Lee (2010) studied some teachers' decisions made over the use of technology. The results indicated that the components of the TPB were predictive of certain behavior. According to Cheon et al (2012) students' intent to rely on mobile learning was also predicted through the components of the TPB. Burns, Houser \& Farris (2018) used the TPB to predict students' behavioral intent in communicating with teachers after applying a suggested model to confirm teacher interaction with students. The 
results indicate the effectiveness of the TPB in predicting behavior in the field of educational communication. Moreover, Bebetsos \& Antoniuo (2009) adopted the TPB to investigate any differences, in terms of gender, in students' attitudes towards the use of computers. The results yielded significant differences in some factors. Abahussain (2017) also used the TPB to detect gender-related differences in reliance on internet-based learning and predicting the intent of faculty members at a newly-established university. The study indicated that there were no significant differences related to gender. Also, the adoption of the internet by faculty members could be predicted through using the TPB.

\section{Statement of the Problem}

The problem of the study is stated as follows: What is the extent to which the faculty members in Egypt and Saudi Arabia are willing to use e-learning in social work education? Is it possible to predict the intent of the faculty members regarding the use of elearning in social work education through utilizing the TPB?

\section{Concepts of the study}

\section{The Readiness of Faculty Members to Use E-learning}

E-Learning Defined as "An educational system and a deliberate and controlled learning process in which the learner undergoes planned and studied learning experiences through interaction with electronic content, using electronic learning resources and media, based on structured learning procedures in an e-learning environment using computer and electronic networks that support and facilitate learning processes at anytime, anywhere (Khamis, 2011, p.1). E-learning is also defined as "the use of various web-based or internet-based technologies for educational purposes" (Nichols, 2003, p.1).

According to TPB, the behavior of interest is defined in terms of its target, action, context, and time (TACT) elements (Ajzen, 2002, p.1).

So, in this study, the readiness of faculty members to use elearning is determined by measuring the components of planned behavior theory (behavioral intent - attitude toward the behaviorsubjective norms - and perceived behavioral control) with a view to prepare and implement a course in social work within the next 12 months.

\section{Hypotheses of the Study}

Hypothesis 1: It is expected that the readiness of faculty members to use e-learning in the education of social work is high. 


\section{Sub-hypotheses:}

1.1 It is expected that the behavioral intention of faculty members to use e-learning in social work education is high.

1.2 It is expected that the attitude toward the behavior of faculty members to use e-learning in social work education is highly positive. 1.3 It is expected that the subjective norms of faculty members to use e-learning in social work education is highly positive.

1.4 It is expected that the perceived behavioral control of faculty members to use e-learning in social work education is high.

Hypothesis 2: There are no statistically significant differences in the behavioral intent and its three components (attitude toward the behavior - subjective norms - perceived behavioral control) due to gender.

Hypothesis 3: There are no statistically significant differences in the behavioral intent and its three components (attitude toward the behavior - subjective norms - perceived behavioral control) due to experience.

Hypothesis 4: The three components of the TPB (attitude toward the behavior - subjective norms - perceived behavioral control) predict the behavioral intent of faculty members towards the use of e-learning in social work education.

\section{Significance of the Study}

The study is significant due to the following:

- To the best of the researcher's knowledge, it is the first study using the TPB in social work in the Arab community.

- Using technology in social work education has many advantages such as modernizing the field of social work education to equal similar fields across the world and also to match other disciplines that rely on the use of technology in learning.

- The demonstration of behavioral intent by faculty members and associated factors, in light of the TPB, helps decision makers to identify what needs to be done to support the decisions and capabilities of faculty members in their use of e-learning in social work.

\section{Theoretical Framework}

The researcher adopts the Theory of Planned Behavior (TPB), "a theory designed to predict and explain human behavior in specific contexts" (Ajzen, 1991, p.181). According to which, human behavior is guided by three main factors: 1. The attitude toward behavior, 2 . The subjective norms, 3. The perceived behavioral control. These 
three components provide important information about behavioral intent (Ajzen, 2012, p.35).

But how are these three factors formed? Ajzen believes that the components of behavioral intent are related to three beliefs that identify and affect them: 1. Behavioral beliefs resulting in positive or negative attitudes toward behavior; 2 . Normative beliefs resulting in the expected social and internal pressures to act; 3 . Control beliefs that gives a perception of an individual's ability to act. (Ajzen, 2002, p.1)

Behavioral intent is a fundamental and pivotal concept in the TPB which assumes that all behaviors are closely related to individuals' intent and that this intent is an indication of individuals' willingness to try and plan for behavior. This intent remains in place until individuals find the right time and opportunity to translate it into action (Ajzen, 1987, p.44). However, this is subject to the existence of actual control over the behavior and the extent to which perceived behavioral control is accurate and realistic whenever used as an agent of the actual capacity to act (Ajzen, 2002, p.1).

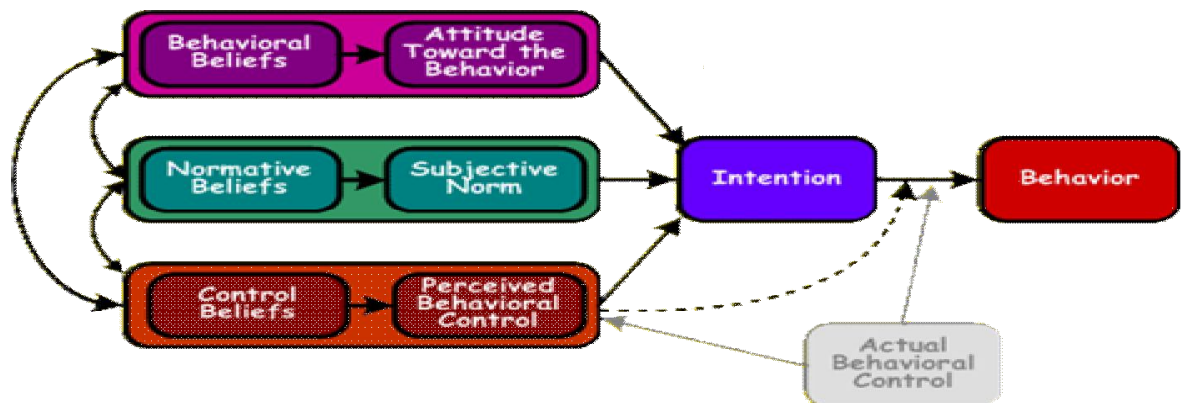

Figure 1: Theory of Planned Behavior Ajzen. (2006)

\section{Concepts of planned behavior theory}

\section{Behavioral intention}

They are indications of how hard people are willing to try, of how much effort they are planning to exert, in order to perform the behavior.( Ajzen, 1987, p.44).

\section{Attitude toward the behavior}

"The degree to which a person has a favorable or unfavorable evaluation or appraisal of the behavior in question".

\section{Subjective norms}

"The perceived social pressure to perform or not to perform the behavior". 


\section{Perceived behavioral control}

"The perceived ease or difficulty of performing the behavior, assumed to reflect past experience as well as anticipated impediments and obstacles" (Ajzen, 1991, p.188).

\section{Methodology of the Study Study Design}

This study is a descriptive study, based on the quantitative survey method, designed to achieve the following objective: Predicting the extent to which faculty members are willing to use elearning in social work education, adopting the Theory of Planned Behavior (TPB).

\section{Sample}

The population of the study consists of faculty members from the colleges and departments of Social Work at public universities in both the Arab Republic of Egypt (5 colleges and 1 department), and the Kingdom of Saudi Arabia (1 college and 8 departments). Their number totaled (523). A simple random sample was selected to represent all colleges and academic departments, totaling (131) or $(25 \%)$ of those who responded to the questionnaire.

The questionnaire link was sent to the participants via e-mail and WhatsApp to invite them to participate in the study.

In the introductory section, the objective of the study was explained, the confidentiality of data was confirmed, it was also confirmed that there are no questions through which the participant's identity may be revealed. Freedom to participate was also ensured by choosing either to "accept" or "refuse" to participate in the study. The duration of data collection was from January 7, 2019 to February 22, 2019.

\section{Study tool}

After obtaining the consent of the author, the study adopted the questionnaire used by Abahussain (2017) in his study on the differences between males and females in the use of e-learning at newly-established Saudi universities and the ability of the Theory of Planned Behavior in predicting the behavioral intention of faculty members to use e-learning. The questionnaire, designed in the light of the elements of the Theory of Planned Behavior (attitude toward the behavior - subjective norm - perceived behavioral control - behavioral intention), consists of 51 elements including the demographic variables and the elements of the Theory of Planned Behavior. Responses are based on a seven-level Likert scale in the positive items 
(Strongly Agree 7654321 strongly Disagree) and the values are revered in the negative ones (for example, Bad 7654321 Good). Abahussain measured the validity and reliability of the questionnaire by analyzing its content to make sure that the items representing the elements of the Theory of Planned Behavior are included. The value of Cronbach's alpha for the dimensions were as follows: attitude toward the behavior (0.96) subjective norm (0.78) perceived behavioral control (0.81), behavioral intention (0.98).

Table (1) Questionnaire dimension

\begin{tabular}{|c|c|c|c|}
\hline \multicolumn{2}{|r|}{ TPB Variable } & \multirow{2}{*}{$\begin{array}{c}\text { Items } \\
\text { Item\#1(Likert- } \\
\text { type Scale of } \\
7 \text { items) }\end{array}$} & \multirow{2}{*}{$\begin{array}{c}\begin{array}{c}\text { Items requiring } \\
\text { revere coding }\end{array} \\
\text { Good, Useful, } \\
\text { Enjoyable, } \\
\text { Important }\end{array}$} \\
\hline \multirow[t]{3}{*}{$\begin{array}{l}\text { Attitude } \\
\text { toward the } \\
\text { behavior }\end{array}$} & $\begin{array}{l}\text { Attitude toward the behavior } \\
\text { (Direct Measure) }\end{array}$ & & \\
\hline & $\begin{array}{c}\text { Belief Strengths (Indirect } \\
\text { Measure) }\end{array}$ & $20,22,24,26$ & 24 \\
\hline & $\begin{array}{c}\text { Outcome Evaluations (Indirect } \\
\text { Measure) }\end{array}$ & $21,23,25,27$ & 21 \\
\hline \multirow[t]{3}{*}{$\begin{array}{l}\text { Subjective } \\
\text { norms }\end{array}$} & $\begin{array}{c}\text { Subjective Norms (Direct } \\
\text { Measure) }\end{array}$ & $9-12$ & $9,10,11,12$ \\
\hline & $\begin{array}{c}\text { Normative Beliefs (Indirect } \\
\text { Measure) }\end{array}$ & $36-39$ & $36,37,38,39$ \\
\hline & $\begin{array}{c}\text { Motivation to Comply (Indirect } \\
\text { Measure) }\end{array}$ & 40 to 43 & \\
\hline $\begin{array}{l}\text { Behavioral } \\
\text { intention }\end{array}$ & $\begin{array}{c}\text { Behavioral Intention (Direct } \\
\text { Measure) }\end{array}$ & $13-15$ & $13,14,15$ \\
\hline \multirow{3}{*}{$\begin{array}{l}\text { Perceived } \\
\text { behavioral } \\
\text { control }\end{array}$} & Perceived Behavioral Control & $16-19$ & 17,19 \\
\hline & $\begin{array}{l}\text { Perceived Behavioral Control- } \\
\text { Tech-Resources (or Perceived } \\
\text { Facilitator) }\end{array}$ & 32,34 & 32,34 \\
\hline & $\begin{array}{c}\text { Perceived Behavioral Control- } \\
\text { Control Beliefs }\end{array}$ & $\begin{array}{c}28,29,30,31 \\
33,35\end{array}$ & 28,30 \\
\hline \multirow[t]{2}{*}{$\begin{array}{l}\text { Demographic } \\
\text { Items }\end{array}$} & Demographic Items & $1-7$ & \\
\hline & Past behavior & $44-51$ & $\begin{aligned} \text { Yes } & =1, \text { No } \\
& =0\end{aligned}$ \\
\hline
\end{tabular}

Validity and Reliability of the questionnaire:

To assess the validity of the questionnaire the authors applied internal consistency of the dimensions and items.

After applying the questionnaire to the sample of 40 Faculty members, the authors calculated the correlation coefficient between:

- the scores of each questionnaire items and the total number of dimension scores.

- the total scores of each dimension of the questionnaire and the total number of questionnaire scores. 


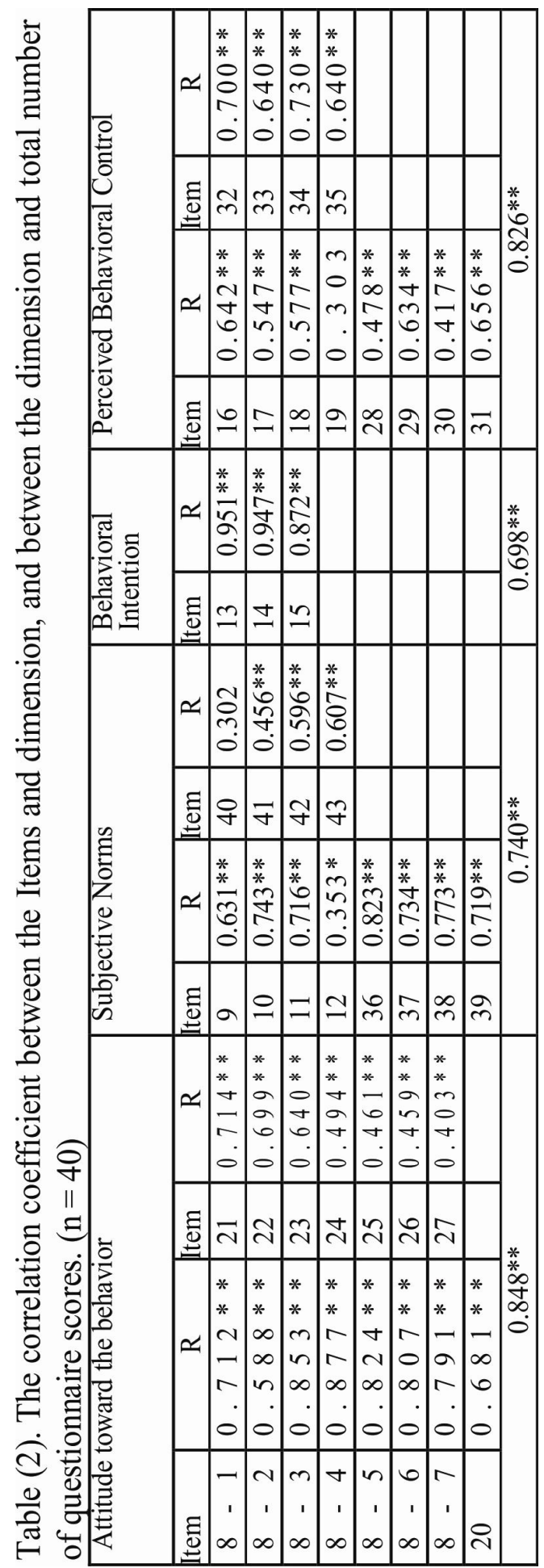




\begin{tabular}{|c|c|}
\hline Egyptian Journal of Social Work (EJSW) & http://ejsw.journals.ekb.eg \\
\hline Print ISSN: 2356-9204 Online ISSN: $2356-9212$ & Vol 10, Issue 1, June 2020 \\
\hline
\end{tabular}

To assess the reliability of the questionnaire the authors applied Cronbach's alpha.

After applying the questionnaire to the sample of 40 faculty members, the authors calculated the Cronbach's alpha to the questionnaire dimensions and questionnaire total.

Table (3) Values of Cronbach's alpha $n=40$

\begin{tabular}{|l|c|c|}
\hline \multicolumn{1}{|c|}{ TPB Variable } & N of Items & Cronbach's Alpha \\
\hline Attitude toward the behavior & 15 & 0.909 \\
\hline Subjective Norms & 12 & 0.849 \\
\hline Perceived behavioral control & 12 & 0.801 \\
\hline Behavioral intention & 3 & 0.906 \\
\hline
\end{tabular}

Table 2 and Table 3 show the validity and reliability of the questionnaire confirming its fitness for use.

\section{Statistical Methods:}

The data was analyzed using SPSS version 26, to calculate the levels of dimensions of readiness, the mean was calculated as the following table shows:

Table (4) Levels of Arithmetic Means for assessing the levels of dimensions of readiness

\begin{tabular}{|c|c|c|c|c|c|c|}
\hline \multirow[t]{2}{*}{ dimensions } & \multirow[t]{2}{*}{$\begin{array}{c}\mathrm{NO} \text { of } \\
\text { item }\end{array}$} & \multirow[t]{2}{*}{$\begin{array}{c}\text { Minimum } \\
\text { expected }\end{array}$} & \multirow[t]{2}{*}{$\begin{array}{l}\text { Maximum } \\
\text { expected }\end{array}$} & $\begin{array}{l}\text { Low } \\
\text { Level }\end{array}$ & $\begin{array}{l}\text { Medium } \\
\text { Level }\end{array}$ & High level \\
\hline & & & & \multicolumn{3}{|c|}{$\begin{array}{l}\text { If the mean value of dimensions } \\
\text { ranged between }\end{array}$} \\
\hline $\begin{array}{l}\text { Attitude toward } \\
\text { the behavior }\end{array}$ & 15 & 15 & 105 & 15 to 45 & 46 to 75 & 76 to 105 \\
\hline Subjective norms & 12 & 12 & 84 & 12 to 36 & 37 to 60 & 61 to 84 \\
\hline $\begin{array}{l}\text { Behavioral } \\
\text { intention }\end{array}$ & 3 & 3 & 21 & 3 to 9 & 10 to 15 & 16 to 21 \\
\hline $\begin{array}{l}\text { Perceived } \\
\text { behavioral } \\
\text { control }\end{array}$ & 12 & 12 & 84 & 12 to 36 & 37 to 60 & 61 to 84 \\
\hline
\end{tabular}




\section{Results of the Study}

\section{1- Demographic variables and previous experiences in e-learning}

Table (5) Demographic variables $(n=131)$

\begin{tabular}{|c|c|c|c|}
\hline Variables & Responses & Frequencies & Percentage \\
\hline \multirow{2}{*}{ Gender } & Male & 65 & $49.62 \%$ \\
\hline & Female & 66 & $50.38 \%$ \\
\hline \multirow{5}{*}{ Age } & less than 30 years & 2 & $1.53 \%$ \\
\hline & $30-$ & 46 & $35.11 \%$ \\
\hline & $40-$ & 53 & $40.46 \%$ \\
\hline & $50-$ & 27 & $20.61 \%$ \\
\hline & 60 years or more & 3 & $2.29 \%$ \\
\hline \multirow{2}{*}{ Place of work } & Egypt & 59 & $45.04 \%$ \\
\hline & Saudi Arabia & 72 & $54.96 \%$ \\
\hline \multirow{3}{*}{ Job } & Assistant Professor & 72 & $54.96 \%$ \\
\hline & Associate Professor & 34 & $25.95 \%$ \\
\hline & Professor & 25 & $19.08 \%$ \\
\hline \multirow{7}{*}{$\begin{array}{l}\text { Years of experience in } \\
\text { university education }\end{array}$} & Less than 5 years & 15 & $11.45 \%$ \\
\hline & $5-$ & 31 & $23.66 \%$ \\
\hline & $10-$ & 22 & $16.79 \%$ \\
\hline & $15-$ & 25 & $19.08 \%$ \\
\hline & $20-$ & 17 & $12.98 \%$ \\
\hline & $25-$ & 7 & $5.34 \%$ \\
\hline & 30 years or more & 14 & $10.69 \%$ \\
\hline \multirow{4}{*}{ Nationality* } & Egyptian & 96 & $73.28 \%$ \\
\hline & Saudi & 30 & $22.90 \%$ \\
\hline & Sudanese & 4 & $3.05 \%$ \\
\hline & Tunisian & 1 & $0.76 \%$ \\
\hline
\end{tabular}

Considering the "Gender" variable, Table (5) shows that the percentage of females in the sample is $50.38 \%$ (66), and that of males is $49.62 \%$ (65). In terms of age, the highest percentage is for those aged 40 to less than 50 years, with $40.46 \%$ (53), followed by those aged 30 to less than $40(35.11 \%)$ (46), third are those aged 50 to less than $60(20.61 \%$ (27), fourth are those 60 years and over $2.29 \%$ (3), and finally are those less than $30(1.53 \%)$ (2). Regarding the "Workplace" variable, the percentage of those working in the Kingdom of Saudi Arabia was 54.96\% (72) and those working in the Arab Republic of Egypt were 45.04\% (59). For the "Job Title" variable, the highest number work as Assistant Professor 54.96\% (72), while the percentage of those working as Associate Professor is 
$25.95 \%$ (34) and the percentage of those working as Professor is $19.08 \%$ (25). For the "Years of Experience" variable, those with experience of 5 years to less than 10 years made up the highest percentage at $23.66 \%$ (31), followed by those with 15 years of experience to less than 20 years at $19.08 \%$ (25), third were those with experience from 10 years to less than 15 years with $16.79 \%$ (22), fourth were those with experience from 20 to less than 25 years, by $12.98 \%$ (17), fifth were those with experience of less than 5 years by $11.45 \%$ (15), sixth were those who have more than 30 years of experience, $10.69 \%$ (14), and last were those with experience from 25 years to less than 30 years, 5.34\% (7). Concerning the "Nationality" variable, Egyptian nationality made up the largest proportion with $73.28 \%$ (96), followed by Saudi with $22.9 \%$ (30), then Sudanese with $3.05 \%$ (4), and finally Tunisian with $0.76 \%$ (1) * The question of nationality was added because there are faculty members from different nationalities working in Saudi Arabia.

Table(6)Previousexperiencesine-learning for thestudysample $(\mathrm{n}=131)$

\begin{tabular}{|l|c|c|c|}
\hline \multicolumn{1}{|c|}{ Experience } & Response & Frequency & Percentage \\
\hline \multirow{2}{*}{ Teaching e-courses } & Yes & 35 & $26.72 \%$ \\
\cline { 2 - 4 } & No & 96 & $73.28 \%$ \\
\hline Participating in developing e-courses & Yes & 32 & $24.43 \%$ \\
\cline { 2 - 4 } & No & 99 & $75.57 \%$ \\
\hline Receiving training about e-courses & Yes & 62 & $47.33 \%$ \\
\cline { 2 - 4 } & No & 69 & $52.67 \%$ \\
\hline Using internet applications in education & Yes & 77 & $58.78 \%$ \\
\cline { 2 - 4 } & No & 54 & $41.22 \%$ \\
\hline
\end{tabular}

It is clear from Table (6) that the lowest percentages in the sample are of those who already had experience in e-teaching; $26.72 \%$ (35) had taught one or more courses in social work using e-learning, but $73.28 \%$ (96) had not had this experience. In addition, $24.43 \%$ (32) of the sample had participated in developing e-courses without teaching them, while $75.57 \%$ (99) had not had this experience. Moreover, $47.33 \%$ (62) had received training about e-learning, while $52.67 \%$ (69) had not. Finally, those who use internet applications such as Facebook, YouTube, Twitter and the like in education totaled $58.78 \%$, (77) outnumbering those who do not at $41.22 \%$ (54). 


\section{Testing the study hypotheses:}

\section{Hypothesis 1:}

Table (7) the mean and Standard Deviations for the Study Variables $(\mathrm{n}=131)$

\begin{tabular}{|l|c|c|c|c|c|}
\hline \multicolumn{1}{|c|}{ The dimensions } & Minimum & Maximum & Mean & $\begin{array}{c}\text { Std. } \\
\text { Deviation }\end{array}$ & $\begin{array}{c}\text { The } \\
\text { level }\end{array}$ \\
\hline Attitude toward the behavior & 45.00 & 105.00 & 77.34 & 15.87 & High \\
\hline Subjective norms & 29.00 & 84.00 & 56.79 & 12.24 & Medium \\
\hline Behavioral intention & 3.00 & 21.00 & 14.71 & 5.48 & Medium \\
\hline $\begin{array}{l}\text { Perceived behavioral } \\
\text { control }\end{array}$ & 31.00 & 83.00 & 57.33 & 10.98 & Medium \\
\hline
\end{tabular}

Table (7) shows that the mean scores on the dimensions of readiness were Medium in 3 dimensions (Subjective norms- behavioral intention- perceived behavioral control) and High in one dimension (Attitude toward the behavior). This indicates that the study sample has a Medium level of readiness for using e-learning in social work education, which supports the first sub-hypothesis only. However, we cannot accept other sub-hypotheses from the first hypothesis of the study, therefore, we cannot accept the first hypothesis of the study.

\section{Hypothesis 2:}

Table (8) Significance of differences in study variables according to gender $(\mathrm{n}=131)$

\begin{tabular}{|c|c|c|c|c|c|c|}
\hline & groups & $\mathrm{N}$ & Mean & Std. Deviation & $\mathrm{T}$ & sig \\
\hline \multirow{2}{*}{$\begin{array}{c}\text { Attitude } \\
\text { toward the } \\
\text { behavior }\end{array}$} & male & 65 & 78.12 & 15.70 & \multirow{2}{*}{$\cdot .557$} & \multirow{2}{*}{$\cdot .579$} \\
\hline & female & 66 & 76.58 & 16.11 & & \\
\hline \multirow{2}{*}{$\begin{array}{l}\text { Subjective } \\
\text { norms }\end{array}$} & male & 65 & 56.03 & 12.14 & \multirow{2}{*}{$-\cdot .700$} & \multirow{2}{*}{$\cdot .485$} \\
\hline & female & 66 & 57.53 & 12.39 & & \\
\hline \multirow{2}{*}{$\begin{array}{l}\text { Behavioral } \\
\text { intention }\end{array}$} & male & 65 & 14.91 & 5.55 & \multirow{2}{*}{$\cdot .409$} & \multirow{2}{*}{$\cdot .683$} \\
\hline & female & 66 & 14.52 & 5.43 & & \\
\hline \multirow{2}{*}{$\begin{array}{c}\text { Perceived } \\
\text { behavioral } \\
\text { control }\end{array}$} & male & 65 & 57.28 & 10.64 & \multirow{2}{*}{$-\cdot .045$} & \multirow{2}{*}{$\cdot .964$} \\
\hline & female & 66 & 57.37 & 11.39 & & \\
\hline
\end{tabular}

It is clear from table (8) that there are no statistically significant differences between males and females across all study variables: attitude toward the behavior - subjective norms behavioral intention - perceived behavioral control. This result validates the second study hypothesis. 


\section{Hypothesis 3:}

Table (9) Significance of Differences in Study Variables According to Previous Experience in E-Learning $(\mathrm{n}=131)$

\begin{tabular}{|c|c|c|c|c|c|c|}
\hline & groups & $\mathrm{N}$ & Mean & Std. Deviation & $\mathrm{T}$ & sig \\
\hline \multirow{2}{*}{$\begin{array}{l}\text { Attitude } \\
\text { toward the } \\
\text { behavior }\end{array}$} & no & 96 & 77.57 & 15.35 & \multirow{2}{*}{$\cdot .261$} & \multirow{2}{*}{$\cdot .795$} \\
\hline & yes & 35 & 76.74 & 17.43 & & \\
\hline \multirow{2}{*}{$\begin{array}{c}\text { Subjective } \\
\text { norms }\end{array}$} & no & 96 & 55.27 & 11.68 & \multirow{2}{*}{-2.389} & \multirow{2}{*}{$\cdot .018$} \\
\hline & yes & 35 & 60.94 & 12.94 & & \\
\hline \multirow{2}{*}{$\begin{array}{l}\text { Behavioral } \\
\text { intention }\end{array}$} & no & 96 & 13.88 & 5.51 & \multirow{2}{*}{-2.977} & \multirow{2}{*}{$\cdot .003$} \\
\hline & yes & 35 & 17.00 & 4.73 & & \\
\hline \multirow{2}{*}{$\begin{array}{c}\text { Perceived } \\
\text { behavioral } \\
\text { control }\end{array}$} & no & 96 & 57.07 & 10.87 & \multirow{2}{*}{-.426} & \multirow{2}{*}{$\cdot .671$} \\
\hline & yes & 35 & 58.00 & 11.40 & & \\
\hline
\end{tabular}

Table (9) shows that there are statistically significant differences at the level of 0.01 between those with previous experience in e-learning and those without, concerning the behavioral intention to use e-learning in social work education, in favor of those with previous experience $(\mathrm{T}=2.977)$. Moreover, the table shows that there are statistically significant differences at the level of 0.05 in the subjective norms variable, in favor of those with previous experience in e-learning $(\mathrm{T}=2.389)$. However, the table shows that there are no statistically significant differences between the variables of the attitude toward the behavior and perceived behavioral control. This result didn't validate the third study hypothesis.

\section{Hypothesis 4:}

Table (10) Summary of Regression Model among Study Variables

\begin{tabular}{|c|c|c|c|c|c|c|c|c|c|}
\hline & & & & & \multicolumn{5}{|c|}{ Change Statistics } \\
\cline { 6 - 10 } Model & $\mathrm{R}$ & $\begin{array}{c}\mathrm{R} \\
\text { Square }\end{array}$ & $\begin{array}{c}\text { Adjusted } \\
\mathrm{R} \text { Square }\end{array}$ & $\begin{array}{c}\text { Error of } \\
\text { the } \\
\text { Estimate }\end{array}$ & $\begin{array}{c}\text { R Square } \\
\text { Change }\end{array}$ & $\begin{array}{c}\mathrm{F} \\
\text { Change }\end{array}$ & $\mathrm{df1}$ & $\mathrm{df2}$ & $\begin{array}{c}\text { Sig. F } \\
\text { Change }\end{array}$ \\
\hline 1 & $.685^{\mathrm{a}}$ & .470 & .457 & 4.03424 & .470 & 37.481 & 3 & 127 & .000 \\
\hline
\end{tabular}

a. Predictors: (Constant), Perceived behavioral control, subjective norms, attitude toward the behavior 
Table (11) Regression Variance Analysis

\begin{tabular}{|c|c|c|c|c|c|c|}
\hline \multicolumn{2}{|c|}{ Model } & $\begin{array}{l}\text { Sum of } \\
\text { Squares }\end{array}$ & df & Mean Square & $\mathrm{F}$ & Sig. \\
\hline \multirow[t]{3}{*}{1} & Regression & 1830.035 & 3 & 610.012 & 37.481 & $.000^{\mathrm{a}}$ \\
\hline & Residual & 2066.942 & 127 & 16.275 & & \\
\hline & Total & 3896.977 & 130 & & & \\
\hline \multicolumn{7}{|c|}{$\begin{array}{l}\text { a. Predictors: (Constant), Perceived behavioral control, subjective norms, attitude } \\
\text { toward the behavior }\end{array}$} \\
\hline
\end{tabular}

Table (12) Result of Regression Analysis

\begin{tabular}{|c|c|c|c|c|c|c|}
\hline \multirow{2}{*}{\multicolumn{2}{|c|}{ Model }} & \multicolumn{2}{|c|}{$\begin{array}{l}\text { Unstandardized } \\
\text { Coefficients }\end{array}$} & \multirow{2}{*}{$\begin{array}{c}\text { Standardized } \\
\text { Coefficients }\end{array}$} & \multirow[b]{2}{*}{$\mathrm{t}$} & \multirow{2}{*}{ Sig. } \\
\hline & & B & Std. Error & & & \\
\hline \multirow[t]{4}{*}{1} & (Constant) & -6.222 & 2.144 & & -2.902 & .004 \\
\hline & $\begin{array}{l}\text { Attitude } \\
\text { toward the } \\
\text { behavior }\end{array}$ & .056 & .029 & .163 & 1.930 & .056 \\
\hline & $\begin{array}{l}\text { Subjective } \\
\text { norms }\end{array}$ & .231 & .034 & .517 & 6.823 & .000 \\
\hline & $\begin{array}{l}\text { Perceived } \\
\text { behavioral } \\
\text { control }\end{array}$ & .060 & .042 & .121 & 1.423 & .157 \\
\hline \multicolumn{4}{|c|}{ a. Dependent Variable: behavioral intention } & & & \\
\hline
\end{tabular}

Regression analysis was used to determine the ability of variables of the Theory of Planned Behavior (attitude toward the behavior - subjective norms - perceived behavioral control) to predict the behavioral intention of faculty members to use e-learning in social work education - a dependent variable. It is clear from table (11) that the Regression Model is statistically significant $(\mathrm{F}=37.481)$ at a level of 0.001. In addition, table (10) points out that there is a statistically significant relationship between the three prediction variables and the dependent variable where the value of $R=0.685$ and the value of $R$ Square $=470$, which indicates that the variables of the Theory of Planned Behavior (attitude toward the behavior - subjective norms perceived behavioral control) explains (0.470) of the variance of the behavioral intention of faculty members to use e-learning in social work education at a level of significance of 0.01. Moreover, table (12) shows that the subjective norms variable is statistically significant in the occurrence of the behavioral intention variable, where $\mathrm{B}=0.231$, at a significant level of 0.01 . Finally, the table shows that the variables 
of attitude toward the behavior and perceived behavioral control are both statistically insignificant with values of $\mathrm{B}=1.63$ and $\mathrm{B}=0.06$ respectively. From this result we can accept the fourth hypothesis of the study.

\section{Discussion}

This study aims to reveal the readiness of faculty members to use e-learning in social work education and explain it in the light of the Theory of Planned Behavior and technological progress in various fields, particularly in university education. It is natural to find that faculty members in social work have a medium behavioral intention to use e-learning in social work education.

In light of the Theory of Planned Behavior, this Medium behavioral intention of the study sample was based on the existence of a highly positive attitude towards e-learning.

The study sample also believe that the enthusiastic support received from the academic leaders and staff interested in the faculty members' views is considered as effective subjective norms of elearning to a moderate degree.

Faculty members believe that they have medium competencies and skills in teaching using e-learning. In addition, some faculty members have a variety of previous experience in the use of e-learning and internet applications in teaching social work, others have received training courses in e-learning or are involved with others in developing e-courses. This is consistent with Abdul-Ghani (2018) in terms of the dependence of some faculty members on the use of some internet programs and applications in teaching social work.

The results indicated that there are no statistically significant differences between males and females, and between faculty members from Saudi Arabia and those from Egypt in their behavioral intention to use e-learning in social work education as well as in the subcomponents of the Theory of Planned Behavior (attitude toward the behavior - subjective norms - perceived behavioral control).

An important finding is that previous experience of a particular behavior has a role in raising the level of behavioral intention to conduct the same behavior again, as there are statistically significant differences in the behavioral intention towards the use of e-learning, as well as the attitude toward the behavior and perceived behavioral control, in favor of those with previous experience in the use of elearning. 
The study examined the ability of the variables of the Theory of Planned Behavior in predicting the behavioral intention. The results indicated that there is a statistically significant relationship between the components of the theory and that the behavioral intention as a dependent variable can be interpreted through the other independent variables (attitude toward the behavior - subjective norms - perceived behavioral control). Moreover, the variable of subjective norms is the most influential in the behavioral intention as it reveals the valued perceptions of those around the individual and their appreciation of the behavior. If these standards indicate the positivity and the importance of conducting the behavior, then the behavioral intention of the individual to conduct this behavior increases, and vice versa.

With less influence in the formation of behavioral intention comes the variable "Attitude", which refers to the subjective assessment of the individual's beliefs towards behavior, followed by the variable "Perceived Behavioral Control", which refers to the skills necessary to conduct the behavior. These skills can be acquired by the individual through training courses and workshops.

Although the results indicate that the variable "Perceived Behavioral Control" is the least influential in the behavioral intention, it is of great importance in converting intention into actual behavior. The Theory of Planned Behavior suggests that the actual behavior is more likely to occur when the individual has the intention to conduct the behavior in the presence of high perceived behavioral control.

This finding is in consistent with Lee, Cerreto \& Lee (2010), Abahussain (2017), and Al-Fraih (2015) that the three variables act as predictors of behavioral intention. In regard to the order of influence of these variables, this finding is consistent with Abahussain (2017) that "attitude" is the most influential variable, but inconsistent with Lee, Cerreto \& Lee. (2010) which reports that "subjective norms" is the most influential variable. This can be attributed to the agreement in the Arab context of this study and that of Abahussain (2017).

\section{Recommendations}

We must keep up with the huge technological progress we are experiencing and benefit from it in the education of social work in Arab countries.

The technological transformation in social work education is not only a positive attitude of faculty members towards the use of elearning, but also subjective norms of academic leaders in social work education institutions towards social work education must be revealed, 
in addition to providing the appropriate infrastructure for this transformation.

Institutions of social work education should work on producing electronic learning resources to be used by faculty members and students in educational situations.

Holding training courses and workshops for faculty members to develop their skills and improve their competencies in the use of elearning in social work education is recommended.

Finally, there should be more studies carried out to assess the Theory of Planned Behavior in social work in the Arab context.

\section{References}

Abahussain, M. M. (2017). Examining Gender Differences toward the Adoption of Online Learning and Predicting the Readiness of Faculty Members in a Middle-Eastern Recently Established Public University. (PhD), Illinois: Northern Illinois University Dekalb.

Abdelghani, Tamer Mohamed (2018). Teaching staff by using Web 2.0 in health care institutions' field training, 12th International Conference on Practice Teaching and Field Education in Health and Social Work 'Innovation in practice learning and field education' St John's College, Oxford, UK, 10-11th September.

Ajzen, I. (1987). Attitudes, traits, and actions: Dispositional prediction of behavior in personality and social psychology. (pp. 1-63). New York, N.Y: Elsevier Science \& Technology. doi:10.1016/S00652601(08)60411-6

Ajzen, I. (1991). The theory of planned behavior. Organizational Behavior and Human Decision Processes, 50(2), 179-211. doi:10.1016/07495978(91)90020-T

Ajzen, I. (2002). Constructing a TPB questionnaire: conceptual and methodological considerations. Retrieved from:

http://chuang.epage.au.edu.tw/ezfiles/168/1168/attach/20/pta_41176 -7688352_57138. pdf

Ajzen, I. (2002). Residual effects of past on later behavior: Habituation and reasoned action perspectives. Personality and Social Psychology Review, 6(2), 107-122. doi:10.1207/S15327957PSPR0602_02

Ajzen, I. (2006). The theory of planned behavior. Retrieved November 14, 2018, from http://www .people.umass.edu/aizen/index.html.

Ajzen, I. (2012). Values, attitudes, and behavior. (pp. 33-38). Wiesbaden: VS Verlag für Sozialwissenschaften. doi:10.1007/978-3-531-18898$0 \_5$

Al-Arabi, Ahmad Obada. (2007). E - learning: its Concept, Systems and the Need for Standards to Control the Quality of its Outcomes. Libraries Now: Egyptian Library Association, No.7, 76 - 101. 
Al-Sherbini, Zeinab Hassan Hassan, and Abdul Hamid, Abdulaziz Tolba. (2012). Using Mobile Phones in a Mobile E-learning Environment and its Impact on the Development of E-content and Publication Skills. Journal of the Faculty of Education in Mansoura: Mansoura University - Faculty of Education, No.79, 631 - 665.

Al-Zufairi, Fayez Monshar. (2004). Educational Goals and Aspirations in E-learning. Mission of Education: Ministry of Education, No. 4, 8490.

Amasha, Mohammad Abdo Ragheb. (2008). E - Learning and Web 2.0. Informatics Journal: Ministry of Education - Vice-Ministry for Development and Planning, No. 24, 18-23.

A-Muhaisen, Ibrahim Abdullah. (1429). Localization of E-learning. Keynote Lecture at the E-Learning Forum: Riyadh. 1-2.

Ba-Mefleh, Faten Bint Saeed. (2006). The Role of the Teacher in the Light of E-learning. Informatics Journal: Ministry of Education - ViceMinistry for Development and Planning, No.16, 22-25.

Bebetsos, E., \& Antonios, P. (2009). Gender differences on attitudes, computer use and physical activity among greek university students. TOJET: The Turkish Online Journal of Educational Technology, $8(2)$

Bozalek, V., \& Matthews, L. (n.d.). E-learning A cross-institutional forum for sharing socio-cultural influences on personal and professional identity. INTERNATIONAL SOCIAL WORK, 52(2), 235.

Burns, M. E., Houser, M. L., \& Farris, K. L. (2018). Theory of planned behavior in the classroom: An examination of the instructor confirmation-interaction model. Higher Education, 75(6), 10911108. doi:10.1007/s10734-017-0187-0

Cheon, J., Lee, S., Crooks, S. M., \& Song, J. (2012). An investigation of mobile learning readiness in higher education based on the theory of planned behavior. Computers \& Education, 59(3), 1054-1064. doi:10.1016/j.compedu.2012.04.015

Deepak, A. C., Wisner, B. L., \& Benton, A. D. (2016). Intersections between Technology, Engaged Learning, and Social Capital in Social Work Education. Social Work Education, 35(3), 310-322.

East, J. F., Lamendola, W., \& Alter, C. (n.d.). Distance education and organizational environment. Journal of Social Work Education, 50(1), 19-33.

Eskander, Kamal Yousef. (1985). Computer-Assisted Learning Between Support and Opposition. Educational Technology: - Arab League Educational, Cultural and Scientific Organization-ALECSO - Arab Center for Educational Technology, No.15, 40-5. 
Francis, J. J., Eccles, M. P., Johnston, M., Walker, A., Grimshaw, J., Foy, R., Kaner, E. F., Smith, L., \& Bonetti, D. (2004). Constructing questionnaires based on the theory of planned behavior: A manual for health services researchers. Newscastle, UK: Centre for Health Services Research, University of Newcastle.

Freeh, Suad bint Abdul Aziz. (2015). Students intend to investigate the intentions of female teachers in adopting Web 2.0 applications in their future teaching using interpretive theory of planned behavior (DTPB). Journal of Educational Sciences: King Saud University College of Education, vol. 27, No.2, 323 - 347.

ITU reveals latest global ICT Development Index country ranking with release of Measuring the Information Society 2017 report. (2017). Telecom Standards, 27(11), 10-11.

Keegan, D., \& Fern Univ., H. (Germany). I. for R. into D. E. (2002). The Future of Learning: From eLearning to mLearning.

Khamis, Mohammad Attia. (2011). Types of Systems and Forms of Elearning Technology. Educational Technology: Egyptian Association for Educational Technology, vol. 21, No.3, 1 - 3.

Knowles, A. J. (n.d.). Pedagogical and policy challenges in implementing E-learning in social work education. Journal of Technology in Human Services, 25(1-2), 17-44.

Lee, J., Cerreto, F. A., \& Lee, J. (2010). Theory of planned behavior and teachers' decisions regarding use of educational technology. Journal of Educational Technology \& Society, 13(1), 152-164

Madoc, J. I., \& Parrott, L. (2005). Virtual Social Work EducationTheory and Experience. Social Work Education, 24(7), 755-768.

Moselhi, Zeinab Mahmoud, \& Mohammad, Amani Abdulkader. (2007). The Challenges and Opportunities Available of University Elearning in Egypt. The Future of Arab.

NASW. (2017). standards for technology in social work. Washington, DC: National Association of Social Workers.

Nichols, M. (2003). A theory for eLearning. Educational Technology \& Society, 6(2), 1-10, Available at http://ifets.ieee.org/periodical/62/1.html 1

Oterholm, I. (n.d.). Online critical reflection in social work education. European Journal of Social Work, 12(3), 363-375.

Othman, Othman Hassan. (2016). Distance E-learning and Knowledge Society. Proceedings of the Eleventh International Conference: Learning in the Era of Digital Technology: The Center of Jil Scientific Research Center, Tripoli: Jil Scientific Research Center and the University of Tipasa, 79-92.

Quinney, A. (2005). 'Placements Online': Student Experiences of a Website to Support Learning in Practice Settings. Social Work Education, 24(4), 439-450. 


\begin{tabular}{|c|c|}
\hline Egyptian Journal of Social Work (EJSW) & http://ejsw.journals.ekb.eg \\
\hline Print ISSN: 2356-9204 Online ISSN: $2356-9212$ & Vol 10, Issue 1, June 2020 \\
\hline
\end{tabular}

Racovita-Szilagyi, L., Carbonero Munoz, D., \& Diaconu, M. (2018). Challenges and opportunities to eLearning in social work education: perspectives from Spain and the United States. EUROPEAN JOURNAL OF SOCIAL WORK, 21(6), 836-849. https://doiorg.sdl.idm.oclc.org/10.1080/13691457.2018.1461066

Salmon, G. (2013). E-tivities $\square$ : The Key to Active Online Learning (Vol. 2nd ed). New York: Routledge.

Sharif, Abdin Mohammad. (2013). The Extent of the Development of Arab University Education Through the Use of E-learning Technology. Educational Journal: Kuwait University - Academic Publication Council, Vol. 27, No.106, 101 - 137.

Shorkey, C. T. (1), \& Uebel, M. (2). (n.d.). History and development of instructional technology and media in social work education. Journal of Social Work Education, 50(2), 247-261.

Webber, M., Currin, L., Groves, N., Hay, D., \& Fernando, N. (n.d.). Social workers can e-learn: Evaluation of a pilot post-qualifying elearning course in research methods and critical appraisal skills for social workers. Social Work Education, 29(1), 48-66. 